\title{
Effects of Dioxins and Polychlorinated Biphenyls (PCBs) on Thyroid Function in Infants Born in Japan: Report from Research on Environmental Health
}

\author{
Nobuo Matsuura1 ${ }^{1}$, Tomoaki Uchiyama ${ }^{1}$, Hiroshi Tada², Yosikazu Nakamura ${ }^{3}$, \\ Naomi Kondo ${ }^{4}$, Masatoshi Morita ${ }^{5}$ and Masaru Fukushi ${ }^{6}$ \\ ${ }^{1}$ Department of Pediatrics, Kitasato University School of Medicine, Kanagawa, ${ }^{2}$ Department \\ of Neonatology, Toho University School of Medicine, Tokyo, ${ }^{3}$ Department of Public Health, \\ Jichi Medical School, Minami-kawachi ${ }^{4}$ Department of Pediatrics, Gifu University School of Medicine, Gifu, \\ ${ }^{5}$ National Institute for Environmental Studies, Regional Environmental Division, Tsukuba \\ ${ }^{6}$ Sapporo Institutes for Public Health, Sapporo, Japan
}

\begin{abstract}
Dioxins (polychlorinated-dibenzo-p-dioxin (PCDD) + polychlorinated-dibenzofuran (PCDF)) and polychlorinated biphenyls (PCBs) are potentially hazardous compounds which have structural similarity to thyroid hormones. Animal studies have demonstrated that PCDDs, PCDFs and PCBs can alter thyroid hormone homeostasis. Both dioxins and PCBs are highly lipophilic and are present in large amounts in human milk samples in highly industrialized, densely populated countries such as Japan and European countries. We collected breast milk from 80 mothers (group A) living in Tokyo, Saitama, Ishikawa, and Osaka prefectures at 5, 30, 150, 300 postpartum days and measured PCDDs, PCDFs and PCBs. The mothers were limited to those aged from 25 to 34 years, and all were primiparous. Blood was taken from infants who were breast-fed at the age of one year. For evaluation of thyroid and immune function, blood was also taken from thirty infants who were bottle-fed (group B) as a control. Serum T4, T3 and FT4 levels were $10.6 \pm 1.6 \mathrm{ug} / \mathrm{dl}, 1.6 \pm 0.2 \mathrm{ng} / \mathrm{ml}, 1.42 \pm 1.25 \mathrm{ng} / \mathrm{dl}$ in Groups A and were $11.1 \pm 2.0 \mathrm{ug} /$ $\mathrm{dl}, 1.7 \pm 0.3 \mathrm{ng} / \mathrm{ml}, 1.43 \pm 0.20 \mathrm{ng} / \mathrm{dl}$ in Group B respectively, and were not significantly different between the two groups. TSH levels were $2.3 \pm 1.0 \mu \mathrm{U} / \mathrm{ml}$ and $1.8 \pm 0.8 \mu \mathrm{U} / \mathrm{ml}$, respectively and were within the normal range, however that of group A was significantly higher than that of group B ( $p=0.027)$. There was no correlation between serum levels of TSH, T3, T4 and FT4 and intake of dioxins. We concluded that intake of dioxins from breast milk in Japanese infants does not alter thyroid function seriously, however, the long-term effects remain to be evaluated.
\end{abstract}

Key words: dioxins, PCBs, breast milk, thyroid function, TEQ

\section{Introduction}

Received: September 27, 2000

Accepted: October 14, 2000

Correspondence: Dr. Nobuo Matsuura, Department of Pediatrics, Kitasato University School of Medicine, 115-1 Kitasato, Sagamihara, 228-8555 Japan.
Polychlorinated-dibenzo-p-dioxin (PCDD) and polychlorinated-dibenzofuran (PCDF), summarized as dioxins, are tricycle aromatic compounds (Fig. 1). Because the number of 
<smiles>Clc1cc2c(cc1Cl)Oc1cc(Cl)c(Cl)cc1O2</smiles>

$2,3,7,8-T C D D$<smiles>Clc1cc2oc3c(Cl)c(Cl)c(Cl)cc3c2cc1Cl</smiles>
2,3,4,7,8-PeCDF

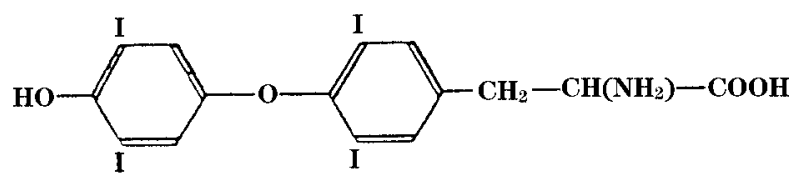

thyroxine (L-3,5, $3^{\prime}, 5^{\prime}$,-tetraiodothyronine)

Fig. 1 Chemical structures of dioxins and T4

chloride atoms can vary between one and eight, there are potentially 75 different PCDD and 135 PCDF congeners. They are mainly formed as byproducts during synthesis of organochlorine chemicals and during the combustion of municipal and harzardous waste. Polychlorinated biphenyl (PCB) is a compilation of 207 possible congeners with different chlorine substitutions. In the late 1970 s, the production and the use of these compounds were banned because their adverse health effects had become evident. However, there are still significant quantities of PCB in use in old transformers and capacitors $(1,2)$.

Both dioxins and PCB are highly lipophilic and chemically stable compounds that accumulate in the food chain. For human beings, the main sources are dairy products, meals and particularly fish in Japan. They are stored mainly in the human adipose tissue, with elimination half-lives of 6 to 10 years. Small amounts of dioxins and PCB can reach the fetus by means of transplacental transport, whereas much higher levels reach breast-fed infants. Dioxins and PCB levels can be especially high in human milk samples in highly industrialized, densely populated countries such as Japan and European countries. Dioxin and PCB have structural similarity to thyroid hormones (Fig. 1), and it has been suggested that PCBs block conversion of T4 to T3 and binding of T3 to thyroid hormone receptor (TR), as well as inhibiting the binding of T3-TR complexes to thyroid hormone elements (TREs) (1-3).

The effects of pre- and postnatal exposure to dioxins and PCBs on thyroid function in pregnant women and their infants have been reported in European countries (1, 4-9), however, there are few reports from Japan (10). The contents of dioxins and PCBs in human milk and their intake by infants through human milk have hitherto not been studied on a large scale in Japan, therefore, in this study we have made a nationwide study from Japan.

\section{Subjects and Methods}

We collected breast milk from 80 mothers (group A) living in Tokyo, Saitama, Ishikawa, and Osaka prefectures at 5, 30, 150, 300 postpartum days and measured fourteen isomers for PCDDs, 15 for PCDFs and 12 for coplanar PCBs (co-PCBs). To express the toxic potency of the mixture of dioxin and PCB in breast milk samples, the toxic equivalent factor (TEF) approach was used. That is, TEF values were assigned to the dioxin and co$\mathrm{PCB}$ to present their relative toxic potencies toward 2,3,7,8-tetrachlorodibenzo-p-dioxin (TCDD), the most toxic dioxin congener, which has a TEF value of one. By multiplying the concentration (pg/g milk fat) and TEF value, the toxic equivalent quantity (TEQ) of each congener was calculated (pg TEQ/g milk fat).

Mothers were limited to those from 25 to 34 years of age, and all the mothers were primiparous and resident for more than 5 years in same area. Intake of dioxin was estimated in two ways: (1) (Dioxin concentration in mother's milk) $\times$ (average intake of mother's milk) (ml/day) $\times$ (days 
until discontinuation of breast-feeding). (2) (Dioxins contents of first mother's milk - dioxin contents of last mother's milk) $\times(\mathrm{BMI})$

At the age of 1 year, blood was taken from 55 of 80 infants of group A for evaluation of thyroid and immune functions. Blood was also taken from 30 infants who were bottle-fed at the age of 1 year as a control (group B).

Dried blood on filter paper was also taken to examine thyroid function and thyroid autoantibodies and was compared with those taken in the newborn period at 5 days. Thyroid and immunologic functions were examined together with growth and developmental assessment in each infant at the age of 1 year.

PCDDs, PCDFs and PCBs in human milk were determined by GC/MS at the Japan Food Research Laboratory. Serum TSH, T3, T4 and FT4 levels were determined by RIA methods at the Specific Reference Laboratory, Tokyo (SPL) using standard assay kits. Dried blood on filter paper was used to determine levels of TSH, FT4 and anti-thyroid antibodies by methods previously reported (11).

The medical ethical committee of the Kitasato University Institutional Review Board (IRB B9805) approved the study protocol as did each other institute's IRB. The parents gave written informed consent.

\section{Results}

\section{Thyroid function in Groups A and B}

Serum T4, T3 and FT4 levels in group A were $10.6 \pm 1.6 \mu \mathrm{g} / \mathrm{dl}, 1.6 \pm 0.2 \mathrm{ng} / \mathrm{ml}$, and $1.42 \pm 1.25 \mathrm{ng} /$ $\mathrm{dl}$, and in Group B were $11.1 \pm 2.0 \mu \mathrm{g} / \mathrm{dl}, 1.7 \pm 0.3$ $\mathrm{ng} / \mathrm{ml}$, and $1.43 \pm 0.20 \mathrm{ng} / \mathrm{dl}$, respectively, and were not significantly different between the two groups. TSH levels were $2.3 \pm 1.0 \mu \mathrm{U} / \mathrm{ml}$ and $1.8 \pm$ $0.8 \mu \mathrm{U} / \mathrm{ml}$, respectively, and were within the normal range, however, that of group A was significantly higher than that of group B $(p=0.027)$ (Table 1).

\section{Thyroid function and intake of dioxins TEQ}

There was no correlation between serum levels of T3, T4, FT4 and estimated intake of dioxins calculated by equation (2) in the method. There was no correlation between the serum level of TSH and estimated intake of the dioxin TEQ in group A (Fig. 1) (r=0.081).

\section{Thyroid autoantibodies}

None of the infants in Groups A and B were positive for anti-thyroglobulin or anti-microsomal antibodies.

Table 1 Thyroid function in infants with breast feeding (Group A) and bottle feeding (Group B) at the age of 1 year

\begin{tabular}{cccccc}
\hline & & $\begin{array}{c}\mathrm{TSH} \\
(\mu \mathrm{U} / \mathrm{ml})\end{array}$ & $\begin{array}{c}\mathrm{T} 3 \\
(\mathrm{ng} / \mathrm{ml})\end{array}$ & $\begin{array}{c}\mathrm{T} 4 \\
(\mu \mathrm{g} / \mathrm{dl})\end{array}$ & $\begin{array}{c}\mathrm{FT} 4 \\
(\mathrm{ng} / \mathrm{dl})\end{array}$ \\
\hline Breast feeding & Mean & 2.3 & 1.6 & 10.6 & 1.42 \\
& S.D. & 1.0 & 0.2 & 1.6 & 0.26 \\
& $\mathrm{n}$ & 55 & 55 & 55 & 55 \\
\hline \multirow{2}{*}{ Bottle feeding } & Mean & 1.8 & 1.7 & 11.1 & 1.43 \\
& S.D. & 0.8 & 0.3 & 2.0 & 0.20 \\
& $\mathrm{n}$ & 32 & 32 & 32 & 32 \\
\hline & $\mathrm{p}$ & 0.027 & 0.18 & 0.271 & 0.828 \\
\hline
\end{tabular}


Table 2 Thyroid function analyzed using dried blood on filter paper for infants aged 1 year and newborn infants

\begin{tabular}{cccc}
\hline & & Breast feeding & Bottle feeding \\
\cline { 3 - 4 } & & $\begin{array}{c}\text { TSH } \\
(\mu \mathrm{U} / \mathrm{ml})\end{array}$ & $\begin{array}{c}\text { TSH } \\
(\mu \mathrm{U} / \mathrm{ml})\end{array}$ \\
\hline \multirow{5}{*}{5 days of age } & Mean & 3.4 & 1.8 \\
& S.D. & 1.9 & 1.2 \\
& $\mathrm{n}$ & 48 & 15 \\
\hline \multirow{2}{*}{ year of age } & Mean & 2.7 & 2.1 \\
& S.D. & 1.1 & 1.0 \\
& $\mathrm{n}$ & 48 & 15 \\
\hline & $\mathrm{p}$ & 0.159 & 0.551 \\
\hline
\end{tabular}

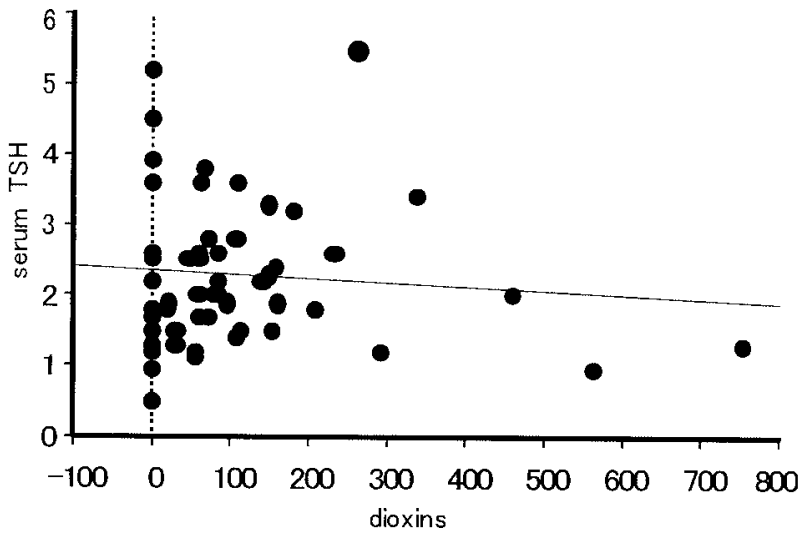

Fig. 2 Correlation between serum TSH level and estimated intake of dioxin TEQ

\section{Correlation between thyroid function at 1 year of age and that of newborn infants at 5 days of age}

The results of thyroid function analyzed using dried blood on filter paper for infants at 1 year of age and 5 days of age are shown in Table 2. The TSH was within normal range in all cases and there were no significant differences between 5 days and 1 year of age or between Groups A and B. There was no significant correlation in dried blood on filter paper of TSH levels at 5 days and at 1 year of age and in none of the samples from dried blood on filter paper was the TSH level more than $10 \mu \mathrm{U} / \mathrm{ml}$.

\section{Discussion}

Although there were significant differences in serum TSH levels between breast-fed and bottle-fed infants, the levels of TSH were within the normal range. Serum T3, T4 and FT4 levels were also within normal ranges and there was no difference between the two groups. It is not clear at present whether intake of dioxins from mother's milk affected serum TSH in the two groups. Pluim et al. reported that mean TSH levels at birth and 1 week after birth were similar in a high-exposure group and low-exposure group, but at the age of 11 weeks, the mean TSH concentration was significantly higher in the high-exposure group $(1.81 \pm 0.19$ vs $2.90 \pm 0.12 \mu \mathrm{U} / \mathrm{dl}$ ) (4). A correlation between dioxin content in mother's milk and thyroid function in mothers as well as in their infants was reported from The Netherlands (1). Higher dioxin levels in human milk correlated with lower levels of maternal thyroid hormone, and with higher plasma levels of TSH in the infants in the 2 nd week and 3rd month after birth. The median TSH levels in the high dioxin-exposed breast-fed infants were $2.3 \mu \mathrm{U} / \mathrm{ml}$ at the second week and $2.0 \mu \mathrm{U} / \mathrm{ml}$ at three months of age, which was almost the same level as in our breast-fed infants at the age of one year. Nagayama et al. reported a significant positive correlation between serum TSH and 
estimated total intakes of dioxins and PCB from breast milk and a negative correlation with T4 (10). The levels of serum TSH and T4 were within normal ranges in their report. Their estimated intake of dioxins and PCBs from the breast milk was calculated by multiplying their TEQ levels in breast milk at 2 to 3 months after birth by the expected intake of breast milk in the Japanese baby, namely $120 \mathrm{ml} / \mathrm{Kg}$ body weight, by the individual duration of breast feeding (days). Since as we reported recently (12), the concentrations of dioxins and PCBs decrease and the intake of milk per Kg of body weight also decreases with the number of days after birth, the intake of dioxins estimated by this method is rather rough and accordingly the data should be treated with great caution.

Effects of lactational exposure to dioxins and related chemicals on immune function $(5,6)$, lymphocyte subpopulations (5), cognitive abilities (8), and growth and development (9) has been reported in human children as well as experimental animals $(13,14)$. Research on the above subjects is now progressing in Japan and will be reported in the near future.

\section{Conclusion}

It was concluded that, although the infants were exposed to fairly large amounts of dioxins and PCBs in breast milk in Japan, the thyroid function at 1 year of age was not impaired seriously. However long term effects remain to be evaluated.

\section{Acknowledgments}

We thank all the parents involved in this study and those persons in the local governments concerned. We also thank Mrs. Michiyo Kanda for preparing the manuscript. This study was supported by the Research on Environmental Health and Research on Children and Families, the Ministry of Health and Welfare, Japan.

\section{References}

1. Koopman-Esseboom C, Morse DC, WeisglasKuperus N, Lutkeschpholt IJ, et al. Effects of dioxins and polychlorinated biphenyls on thyroid hormone status of pregnant women and their infants. Pediatr Res 1994; 36: 468-73.

2. Sher ES, Xu XM, Adams PM, Craft CM, et al. The effects of thyroid hormone level and action in developing brain: are these targets for the actions of polychlorinated biphenyls and dioxins? Toxicology Indust Health 1998; 14: 121-58.

3. Hause P, McMillin JM, Bhatara VS. Resistance to thyroid hormones: Implications for neurodevelopmental research on the effects of thyroid hormone disruptors. Toxicology Indust Health 1998; 14: 85-101.

4. Pluim HJ, de Vijlder JM, Olie K, Kok JH, et al. Effects of pre- and postnatal exposure to chlorinated dioxins and furans on human neonatal thyroid hormone concentrations. Environ Health Perspect 1993; 101: 505-8.

5. Weisglas-Kuperus N, Sas TC, Koopman-Esseboom C, De Ridder MAJ, et al. Immunologic effects of background prenatal and postnatal exposure to dioxins and polychlorinated biphenyls in Dutch infants. Pediar Res 1995; 38: 404-10.

6. Trypbonas H. The impact of PCBs and dioxins on children's health: Immunological consideration. Canad J Publ Health 1998; 89 (Suppl 1): s49-s52.

7. Lackmann GM, Angere J, Salzberger U, Tollner U. Influence of maternal age and duration of pregnancy on serum concentrations of polychlorinated biphenyls and hexachlorobenzene in full-term neonates. Biol Neonates 1999; 76: 214-9.

8. Patadin S, Lanting CL, Mulder PGH, Bersman ER, et al. Effects of environmental exposure to polychlorinated biphenyls and dioxins on cognitive abilities in Dutch children at 42 months of age. J Pediatr 1999; 134: 33-41.

9. Gladen BC, Ragan NB, Ragan WJ. Pubertal growth and development and prenatal and lactational exposure to polychlorinated biphenyls and chlorodiphenyl dichloroethene. J Pediatr 2000; 136: 490-6.

10. Nagayama J, Iida $T$, Hirakawa $H$, Matsueda $T$. 
Effects of lactational exposure to chlorinated dioxins and related chemicals on thyroid functions in Japanese babies. Organohalogen Comp 1997; 33: 446-50.

11. Fukushi M, Takasugi N, Fujieda K, Matsuura N. Measurement of free thyroxine and free triiodothyronine in dried blood on filter paper and its application to neonatal thyroid screening. J Jpn Pediatr Soc 1987; 91: 5-11.

12. Tada H, Nakamura Y, Matsuura N, Kondo N, et al. Annual report from Research on Environmental Health and Research on Children and Families, the Ministry of Health and Welfare, Japan 1999; 1133.
13. Corey DA, Juarerez de Ku LM, Bingman VP, Meserve LA. Effects of exposure to polychlorinated biphenyl (PCB) from conception on growth, and development of endocrine, neurochemical, and cognitive measures in 60 day old rats. Growth Develop Aging 1996; 60: 131-43.

14. Rosiak KL, Seo BW, Chu I, Francis BM. Effects of maternal exposure to chlorinated diphenyl ethers on thyroid hormone concentrations in maternal and juvenile rats. J Environ Sci Health 1997; B32: 377-93. 